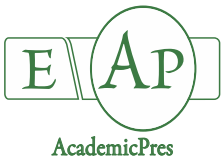

Ecseri K and Honfi P (2020)

Notulae Botanicae Horti Agrobotanici Cluj-Napoca 47(4):480-491

DOI: $10.15835 /$ nbha48111812

Research Article

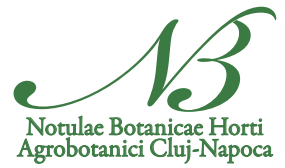

\title{
Comparison of European Archaeophyte lists in the light of distribution data
}

\author{
Károly ECSERI ${ }^{1}$, Péter HONFI ${ }^{2 *}$ \\ ${ }^{1}$ John von Neumann University, Faculty of Horticulture and Rural Development, Department of Horticulture, 1-3, Mészöly Gyula \\ Square6000, Kecskemét, Hungary; ecseri.karoly@kvk.uni-neumann.hu \\ ${ }^{2}$ Szent István University, Faculty of Horticultural Science, Institute of Sustainable Horticulture, Department of Floriculture and \\ Dendrology, 29-43.Villányi Street, 1118, Budapest, Hungary; honfi.peter@kertk.szie.hu ("corresponding author)
}

\begin{abstract}
Currently is not available a complex archaeophyte definition based on the same criteria in Europe, and it cause significant anomalies between neighbouring countries. The main aim of our work was to provide the criteria which based on the available lists and chorological information. For this purpose, the archaeophyte flora of 15 European countries was compared in our research. The list of available resources has been revised and completed, taking into account the distribution data of the species. The lists were merged to contain 560 species. The majority of the plants in the merged list belong to the Asteraceae and Poaceae families with 74 and 55 species, respectively. The Chenopodium genus is characterized by the most frequent occurrence ( 14 species). More than half of the plants are annual and 151 species belong to Eurasian geoelements. The greatest numbers of species were observed in Crete (461 species) and Greece (460 species) and the smallest numbers were observed in Ireland (240 species) and England (241 species). In case of individual countries, plants with composite flowers, annual life form and Eurasian elements represent the highest volume, but the number of southern geoelements is also significant. All lists included anaecophytes archaeophytes. Comparison of revised lists showed $83-99 \%$ similarity. Using with this method can be formed an international archaeophyte database, which based on phytogeographical distribution and helps future researchers.
\end{abstract}

Keywords: archaeobotany; chorology; phytogeography; segetal plants; taxonomy

\section{Introduction}

Archaeophytes are species that were originally non-native to the area and were introduced and established in the specific area before the year 1500 (or 1492) (Terpó et al., 1999; Pysek et al., 2012; Maslo and Abadžic, 2015). In European flora research, they are also called "oldcomer plants" (Balogh, 2003), old anthropophytes, distinguished from neophytes (Zając et al., 2009) which came into the European flora after the discovery of the American continent. They are also interpreted as 'almost native' species, or in recent publications (together with neophytes) as allophytes, aliens, or non-native species. In many cases, they are regarded as cultural relics indicating a nomadic, migrant lifestyle of people (Comin and Poldini, 2009). Most species in Slovakia are naturalized and have a relatively stable population (Medvecká et al., 2012). At the same 
time, Belgium does not distinguish between native species and archaeophytes due to uncertain data and missing sources (Verloove, 2006).

There are five criteria for their identification including:

- There is evidence of their presence based on archaeological excavations, and current habitat and distribution in Europe and beyond (Preston et al., 2004).

- There are no fossils of the taxon from ages before the Neolithic. This is the period (from about 5700 $\mathrm{BC}$ ) when the first cultivated cereal fields were formed, with the first archaeophyte weed species (Hajnalová et al., 1993).

- The individuals and populations of the taxon are mainly found in artificial habitats, especially in agricultural areas (Celesti-Grapow et al., 2010), while neophytes dominate the ruderal areas of settlements (Lososová et al., 2006).

- Archaeophytes are not capable of invasion; they do not spread suddenly in the habitat (Preston et al., 2004).

- In addition, the uncertain native status in Europe, historical data from 1700, and spreading in 'New Europe' (e.g. North America) is a prerequisite (Preston et al., 2004). These criteria vary slightly from country to country due to differences in the historical and geographical background (Williamson $e t$ al., 2008). In northern European areas, the border line is slightly later: originally non-native species are considered to belong to this group that reached Norway, Iceland and Estonia before 1650, before 1770 and the middle of the $18^{\text {th }}$ century, respectively (Ööpik et al., 2008; Wąsowicz 2018). This anomaly would have made it difficult to compile a uniform list, and the lack of detailed archaeophytic flora in the Scandinavian literature, we do not analyse this area.

Although it is not a criterion, Lososová et al. (2006) state that species belonging to this group are the most common annual species that are insect or self-pollinated, R-strategists, reproducing by seeds, and have a permanent seed bank.

Well-known archaeophytes research works analyse the flora of individual countries. However, it is important to note that a taxon does not necessarily have the same judgment in different countries in terms of whether it can be considered an archaeophyte. It is explained by the definition itself: a given plant endemism in the area or the time of its introduction should be examined to determine whether the taxon in question can be considered to be an archaeophyte in that area. Obviously, it may vary from country to country, so that a taxon is considered an archaeophyte in a country is, while it might be native or neophyte in another country. It adds complexity to the judgment of this category. Example the Artemisia and Brassica genera have several species of archaeophytes in the Czech Republic (Pysek et al., 2012), but they are not listed in Poland (Zając et al., 2009; Tokarska-Guzik et al., 2010) since they are distributed to this area (Anastasiu and Negrean, 2005). In the Czech Republic, more Allium species are also referred to as "oldcomer plants" but none of them listed in Slovakia (Medvecká et al., 2012). Therefore, based on our results, we aimed to propose a supplement to the available definition of archaeophytes.

The other problem arises from the fact that the distribution of plants not linked to the administrative boundaries of the countries, it is primarily determined by climatic and edaphic factors and by the phytogeographical features. Currently is not available a complex archaeophytes list based on the same criteria in Europe, so the main aim of our work was to provide the criteria which based on the available lists. Use of these criteria the synthesized merged European archaeophytes list can be compiled. Based on these results, we have also prepared a merged list, but in this study, we do not aim at simply notification of the list, but analysing it and presenting the relationships. We examined the list for taxonomy (families, genera), life forms and geoelements, with the aim of presenting significant and less significant archaeophyte groups and emphasizing proportions. It is also important to compare the lists of neighbouring countries, especially in the case of nations with close geographical and historical relationship. 


\section{Materials and Methods}

\section{Data source}

The basis for our analysis was the archaeophyte list of 15 European countries including:

- Bosnia and Herzegovina (Maslo, 2014a; Maslo, 2014b; Maslo and Abadžić, 2015; Sarajlic and Jogan, 2017),

- Crete (Cin D’Agata et al., 2009) (We examined the Crete list separately from Greece because of its unique geographical features),

- Croatia (Nikolić, 2018),

- Czech Republic (Pysek et al., 2012),

- England (Preston et al., 2004),

- France (Brun, 2009),

- Germany (Hofmeister and Garve, 2006),

- Greece (Arianoutsou et al., 2010),

- Hungary (Terpó et al., 1999),

- Ireland (Williamson et al., 2008),

- Italy (Celesti-Grapow et al., 2009; Comin and Poldini, 2009),

- Poland (Zając et al., 2009, Tokarska-Guzik et al., 2010),

- Slovakia (Medvecká et al., 2012),

- Slovenia (Jogan et al., 2012),

- Switzerland (Richner, 2014) and

- Ukraine (Protopopova and Shevera, 2014).

Countries with available literature on archaeophytes were included in the study. Where more sources were available, the lists were merged (the taxon was included in the common list if at least one of the sources mentioned it).

Prior to analysing the data, the names of the plants were checked for the common nomenclature and the current names were improved (The International Plant Names Index, 2012; The Plant List, 2013). The cladistic system APG IV was used to determine the taxonomy of plants (Stevens, 2017). To determine the lifestyle of taxa, the handbook of plants (Simon, 2000; Király, 2009) and the lists published for the countries were used. The gene centres of the species are shown on the basis of the lists and the Euro-Mediterranean plant diversity database (Euro+Med PlantBase, 2006) was used. Erhardt et al. (2002), Erhardt et al. (2008) were used as a source of distribution data. For which taxon no data were found in these papers, or the data reported were not clear (e.g. cultivated plant, hybrid or anaecophyte), the original national lists were used as the basis for determining the distribution. If the taxon had been non-native to Europe according to the above sources, it was omitted from the list (e.g. Citrus limon and Cucumis sativus). To determine the geoelements, Soó (1964-1985), Meusel et al. (1965), Simon (2000) were used. For which taxon no data were found in these papers, was used to distribution data and georeferenced from Global Biodivesity Information Facility database (GBIF.org, 2019) to determine the geoelements category. In the case of hybrid species, a cross-section of the parent species area types was taken.

One-way analysis of variance (ANOVA) was carried out and significant differences were calculated according to Tukey test, with $P \leq 0.05$ being considered significant in all analyses. Statistical analyses were carried out using the SPSS 20 software (IBM, New York, US). 


\section{Results}

\section{Analysis of the merged European list}

The following considerations have been taken into account in the establishment of the united European archaeophyte list:

- the taxon should meet the specific criteria for the definition of archaeophytes according to Hajnalová, 1993; Preston et al., 2004; Celesti-Grapow et al., 2010;

- plants listed under different (synonym) names in national lists should be listed only once, under a name approved by the International Nomenclature Committee;

- the current natural distribution of taxon should be classified as native in Europe and we recommend adding this phytogeographic criterion to the definition, that is, plants that are exclusively cultivated and not found in natural or seminatural populations in Europe (e.g. Arundo donax, Cucumis melo, Cyperus papyrus, etc.) we do not recommend to be called archeophyte species.

The merged list of 15 countries contains 617 taxa. Considering distribution data as described above, we found that 57 taxa are not native in the European countries we investigated. Within the remaining 560 archaeophytes, 533 species, 12 under species taxonomic units (subspecies, variety or form) and 15 hybrids were determined.

The taxa included in the complex list belong to 62 different plant families. Two of those families are gymnosperms, six are monocotyledonous and 54 families are dicotyledonous. The number of species per family ranges between one and 71 . For 24 of all families, only one species was listed. There are 25 families with two to ten species, and 13 families with more than ten taxa in the list. The Brassicaceae, Fabaceae, Poaceae and Asteraceae families comprise 45, 42, 55 and 71 species, respectively. The last accounts for $13 \%$ of the number of species in the merged list.

Examining the 281 genera included in the list, most of them (168 genera) are represented by only one taxon, and there are at least two species in the merged list for 113 genera. 22 genera have five or more species; eight genera contain eight or more species. Those include Arctium, Bromus, Carduus, Chenopodium, Lamium, Lathyrus, Veronica and Vicia. Of these, most taxa (14 species) can be observed in the Chenopodium genus. The success of the four largest genera with the highest taxon numbers (Bromus, Chenopodium, Lathyrus and Vicia) might be due to their intensive agricultural utilization.

Studying plant life forms, ten different categories (or overlaps among them) were observed with nine double categories. The number of species in each lifestyle category ranged from one to 296 in the list. The latter value represents the number of annual plants, the therophytes $(\mathrm{Th})$ group, which takes $52.9 \%$ of the total list. In addition, there is also a significant number of perennials - hemicryptophytes $(\mathrm{H})$ - (76) and annual-biennials - therophytes-hemitherophytes (Th-TH) - (63). Woody species (including chamaephytes) are represented by a total of 55 plants. This is only $9.8 \%$ of the total list, while the herbaceous species took $90.2 \%$ (505).

Among the archaeophytes included in the merged list can be found the members of 11 geoelements (the first taxon-specific flora element reported in the literature was considered). These are: Eurasian (151 taxa, of which 88 taxa have Mediterranean effect), Mediterranean (103 taxa), European (62 taxa), sub-Mediterranean (58 taxa), South Eurasian (51 taxa), cosmopolitan (50 taxa), Atlantic (24 taxa, almost all have Mediterranean influence), Central European (19 taxa), Eastern Mediterranean-sub-Mediterranean (16 taxa, these are the archaeophytes found in south-eastern Europe), Pontic (14 taxa), circumpolar (12 taxa). Based on these results, the number of "global" (comprising at least two continents) geoelements in the merged list is 264, while the number of "local" archaeophytes with a smaller area is 296. The widespread distribution of the "global" archaeophytes group can also be observed in the areas examined by us: 132 of the 264 taxa can be found in all examined lists, while the number of "global" archaeophytes in the single list is 13 . On average, one of these plants is found in 12.84 of the 16 European lists examined.

Among the "local", regional distributed archaeophytes there can be found only 66 taxa in all examined lists, at the same time 34 plants were present in only one area. These can be found averagely in 9.18 lists. The 
484

number of southern flora elements is 228, not including significant Mediterranean impacts in the Eurasian category and other categories. In the literature, in 353 of the 560 taxa used the word "Mediterranean" in chorological characterisation.

\section{The comparison of country lists}

\section{The size of the lists}

Observing the size of the corrected lists, it can be stated that Crete has the largest archaeophyte list (comprising 461 species, more than $82.1 \%$ of the merged list). In addition, Greece ( 460 species), Croatia (451 taxa), Italy (450 taxa), Bosnia and Herzegovina (446 taxa), Slovenia (438 taxa) and France (402 taxa) are also very important countries. The smallest number of archaeophyte plants is registered in the Irish (240) and in English (241) floras. The other countries surveyed (Ukraine, Switzerland, Hungary, Slovakia, Poland, Czech Republic and Germany) have values between 300 and 400 species. In addition, we have data from the Romanian archaeophyte list, which contains 51 species (Anastasiu and Negrean, 2005), and the size of the Finnish list is also mentioned in several publications: according to Suominen and Hämet-Ahti (1993), 192 species and 228 taxonomic units, while Pykälä (1998) reported on 100-140 species and 120-170 taxonomic units. The latter seems probable; while the number of Romanian archaeophytes is likely to be higher in terms of distribution data (at least 317 species might be included in the list of this country from the merged list). Possible list of Icelandic archaeophytes contain 19 species (Wąsowicz, 2018).

Considering the size of each country (Kovács and Szigeti, 2007) in relation to the national lists, it can be stated that in average most archaeophytes are found in Crete. The number of species in Slovenia is also high. The smallest number of plants related to the area occurred in Poland, Great Britain, Germany, France and Ukraine. Each of these countries has an area exceeding $100,000 \mathrm{~km}^{2}$.

Pairwise comparison after the analysis of variances has separated six groups based on the size of the lists. The number of species was significantly lowest in two western European islands (Ireland and Great Britain), while the group with the highest values comprises Greece and Crete, the Balkan Peninsula and Italy. Germany, Ukraine, Switzerland and Poland also have smaller species numbers. The other East-Central European and Central European countries as well as France have lists of intermediate sizes (Figure 1).

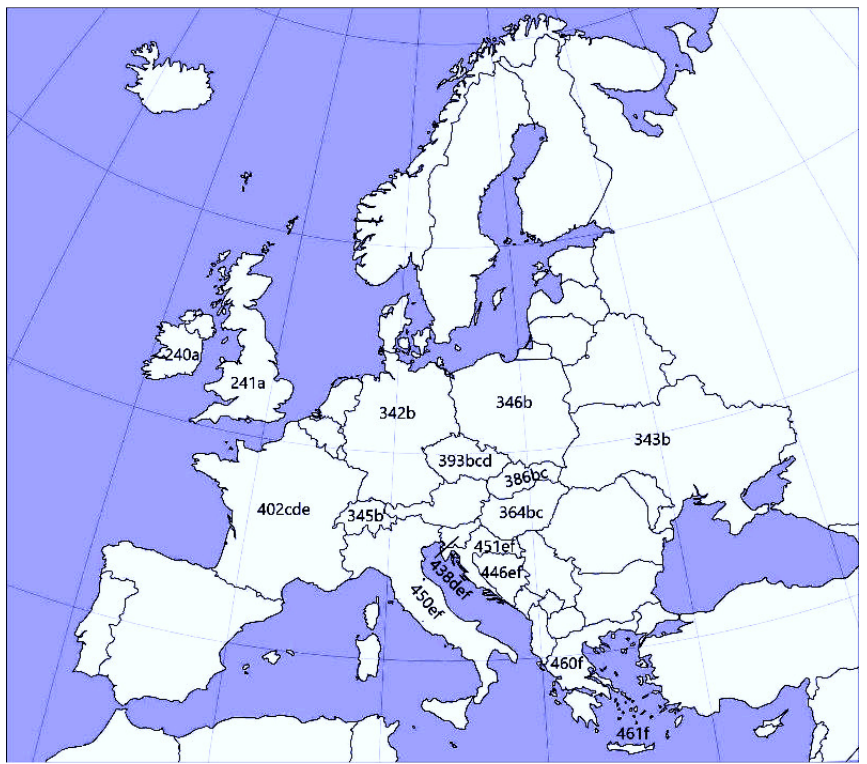

Figure 1. Taxon number of corrected archaeophytes lists in Europe

Note: letters after numbers represent significantly homogeneous groups (Tukey test for $\mathrm{SL}=0.05$ ) Comparison of the lists of neighbouring countries or territories 
1. Great Britain and Ireland (the ratio of identical taxa compared to the merged list of both countries: 99.59\%)

For both islands, the length of the modified archaeophyte list is very short, with 241 and 240 species. The difference between the two areas is coming from a single taxon (Artemisia pontica). It follows that the Irish list is a perfect subset of English.

2. Greece and Crete (the ratio of identical taxa compared to the merged list of both countries: 95.54\%)

There are 450 species in each of these areas. Comparing the 10 and 11 species contributing to the difference between the two areas, it can be stated that in case of the island, six of them are woody species; while among the archaeophytes in Greece only one (Salvia officinalis) belongs to the woody plants.

3. Croatia and Bosnia and Herzegovina (the ratio of identical taxa compared to the merged list of both countries: $95.00 \%$ )

The relationship of the two neighbouring states according to the composition of the archaeophyte flora has been statistically confirmed with pairwise comparison, so we can also make a more detailed comparison. The taxon number is high in both countries ( 451 and 446), and we found 437 identical species. Number of different plants is 14 in Croatia and nine in Bosnia and Herzegovina. The difference between the two countries is mainly due to the six Triticum species in Croatia, which are not or only rarely found in the other countries examined.

4. Czech Republic and Slovakia (the ratio of identical taxa compared to the merged list of both countries: 90.93\%)

A similar list size (393 and 386 species) or a geographical location justified comparing these two neighbouring states. There are 371 species in both lists. There are only 15 species that can find only in Slovakia, and 22 species occurring only in Czech Republic, with a high proportion of hybrids. Most of the differences are the species of Allium, Arctium, Carduus and Chenopodium.

5. Germany and Poland (the ratio of identical taxa compared to the merged list of both countries: $85.95 \%)$

The two countries also have a similar geographical location, they share close historical relationships with each other, and their lists are also similar in size (342 and 346 taxa). The number of identical species is 318 . Only in Germany can find 24 species and 28 species occurring just in Poland.

6. Italy and Slovenia (the ratio of identical taxa compared to the merged list of both countries: $85.00 \%$ )

The archaeophyte lists of the two neighbouring areas are very similar in size ( 450 and 438 species). The number of identical plants is 408 . There are only 42 species that can find only in Italy and 30 species occurring only in Slovenia.

7. Hungary and Ukraine (the ratio of identical taxa compared to the merged list of both countries: $83.64 \%$ )

The modified archaeophyte list of Hungary contains 364 plants, while Ukraine has 343 plants. The number of identical species in this case is 322 . There are only 21 species that can be found only in Ukraine and another 42 species occurring only in Hungary.

\section{Distribution of individual lists based on the frequency of plant families}

From the 62 families present in the merged list, 60 families are represented in at least three of the 15 countries. However, 36 families are listed in all the 15 areas studied. Examining the percentage distribution of families having more than ten species in the merged list (Table 1), Asteraceae is the most frequent family with species all of the countries. This is probably due to the diversified seed dispersal strategy (anemochory/zoochory/anthropochory) (Comin and Poldini, 2009).

Table 1. Percentage (\%) of plant families with high taxon numbers compared to the total number of archaeophytes, in the 15 national archaeophyte lists and the merged European archaeophyte list 
Ecseri K and Honfi P (2020). Not Bot Horti Agrobo 48(1):480-491

486

\begin{tabular}{|c|c|c|c|c|c|c|c|c|c|c|c|c|c|c|c|c|c|}
\hline$\approx \widetilde{a}$ & $\underset{i}{\stackrel{f}{i}}$ & $\stackrel{\vec{j}}{i}$ & $\hat{i}$ & 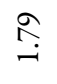 & $\underset{i}{\stackrel{a}{i}}$ & $\stackrel{n}{\hat{o}}$ & $\stackrel{\cong}{\stackrel{\sim}{\sim}}$ & $\underset{i}{\stackrel{P}{+}}$ & $\stackrel{\infty}{\stackrel{\infty}{i}}$ & 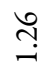 & $\underset{i}{i}$ & กิ & $\stackrel{\infty}{\circ}$ & $\tilde{\widehat{N}}$ & $\stackrel{\overbrace{}}{i}$ & $\stackrel{+r}{i}$ & $\widetilde{\widetilde{i}}$ \\
\hline$\stackrel{\circ}{\stackrel{a}{a}}$ & 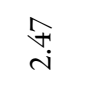 & ते & $\underset{\mathrm{H}}{\mathbb{Z}}$ & $\stackrel{\circ}{\circ}$ & $\stackrel{\text { I }}{\text { i }}$ & $\underset{\text { Ș }}{+}$ & $\stackrel{i}{i}$ & 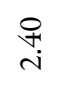 & $\stackrel{n}{\hat{i}}$ & $\overrightarrow{\widetilde{n}}$ & $\underset{i}{i}$ & $\stackrel{\text { i }}{\circ}$ & $\underset{i}{i}$ & $\tilde{\widehat{i}}$ & Sु & & तु \\
\hline$\stackrel{\alpha}{a}$ & $\stackrel{\infty}{\infty}$ & $\begin{array}{l}\mathscr{\infty} \\
i \\
i\end{array}$ & 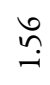 & $\hat{n}$ & $\stackrel{\text { fे }}{\text { : }}$ & $\stackrel{n}{a}$ & $\widehat{\widehat{~}}$ & $\stackrel{+}{\stackrel{+}{S}}$ & $\underset{\sim}{\tilde{r}}$ & $\hat{\hat{i}}$ & 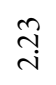 & 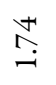 & $\stackrel{\infty}{m}$ & تُ & $\stackrel{+}{\stackrel{N}{-}}$ & $\stackrel{ }{\stackrel{0}{i}}$ & $\vec{\sim}$ \\
\hline$\approx \widetilde{\varrho}$ & $\begin{array}{l}\stackrel{0}{0} \\
\dot{m}\end{array}$ & $\stackrel{R}{\stackrel{r}{n}}$ & 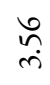 & $\tilde{m}$ & 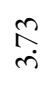 & $\tilde{\sim}$ & $\stackrel{\triangleq}{\leftrightarrows}$ & $\stackrel{R}{i}$ & $\vec{m}$ & $\stackrel{\infty}{\underset{+}{+}}$ & $\stackrel{+}{m}$ & $\stackrel{\vec{m}}{\vec{m}}$ & $\underset{m}{\stackrel{\sim}{r}}$ & $\begin{array}{l}\text { b } \\
\dot{r}\end{array}$ & $\underset{+}{\stackrel{f}{\sim}}$ & $\widehat{\widehat{i}}$ & $\vec{\sim}$ \\
\hline $\bar{a} \widehat{\varrho}$ & $\underset{+}{\stackrel{H}{*}}$ & $\overrightarrow{\dot{m}}$ & $\underset{+}{\stackrel{8}{+}}$ & $\stackrel{\leftrightarrow}{\stackrel{+}{+}}$ & $\stackrel{\substack{++}}{+}$ & $\begin{array}{l}\stackrel{\infty}{\sim} \\
\text { in }\end{array}$ & $\begin{array}{l}\infty \\
\infty \\
i n\end{array}$ & $\tilde{\dot{m}}$ & 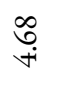 & $\begin{array}{l}\stackrel{0}{\infty} \\
\text { in }\end{array}$ & $\stackrel{\stackrel{\sim}{+}}{+}$ & $\underset{+}{\stackrel{*}{*}}$ & $\underset{\underset{+}{*}}{\stackrel{\sim}{*}}$ & $\underset{+}{\stackrel{T}{*}}$ & $\stackrel{\overbrace{}}{\sim}$ & 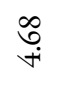 & $\stackrel{n}{n}$ \\
\hline$\tilde{u} \precsim$ & $\underset{+}{\stackrel{N}{*}}$ & $\hat{n}$ & $\underset{+}{\hat{\sigma}}$ & $\stackrel{\sim}{\infty}$ & 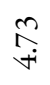 & $\hat{n}$ & $\hat{\sigma}$ & $\stackrel{\infty}{\stackrel{\sim}{*}}$ & $\overrightarrow{\tilde{n}}$ & హ్ర & $\stackrel{\sim}{\stackrel{\sim}{+}}$ & $\overrightarrow{\tilde{n}}$ & $\stackrel{\vec{\sim}}{\sim}$ & $\underset{\infty}{\overrightarrow{+}}$ & $\tilde{\sim}$ & $\begin{array}{l}\hat{\infty} \\
\dot{n}\end{array}$ & $\hat{\sigma}$ \\
\hline 毒 $\widehat{\varrho}$ & ๗ે. & $\stackrel{\leftrightarrow}{\leftrightarrow}$ & $\stackrel{\overbrace{}}{n}$ & $\stackrel{\sim}{*}$ & 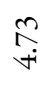 & ㄱ. & $\stackrel{\infty}{\stackrel{\leftrightarrow}{+}}$ & $\stackrel{\sim}{n}$ & $\stackrel{\widehat{\hat{n}}}{i n}$ & 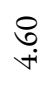 & $\stackrel{7}{\sim}$ & ô. & $\tilde{\widehat{\sigma}}$ & $\underset{f}{\stackrel{f}{*}}$ & 굼 & $\frac{\pi}{\sigma}$ & $\stackrel{\infty}{\vec{n}}$ \\
\hline$\widetilde{\Im} \widehat{\varrho}$ & $\underset{+}{\stackrel{N}{*}}$ & $\hat{n}$ & $\underset{+}{\stackrel{\alpha}{+}}$ & $\stackrel{\circ}{\stackrel{1}{n}}$ & $\stackrel{\infty}{+}$ & $\begin{array}{l}\hat{\infty} \\
\text { in }\end{array}$ & $\stackrel{\infty}{\circ}$ & $\underset{\leftarrow}{\stackrel{\overbrace{}}{+}}$ & 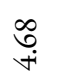 & $\vec{\pi}$ & $\stackrel{\sim}{\stackrel{f}{+}}$ & $\stackrel{\curvearrowright}{\dot{q}}$ & $\underset{+}{\stackrel{+}{+}}$ & 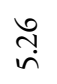 & $\underset{+}{\stackrel{t}{t}}$ & $\stackrel{\widehat{\alpha}}{+}$ & $\stackrel{i r}{n}$ \\
\hline दे & ๗ె? & 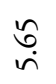 & $\stackrel{\overbrace{}}{n}$ & 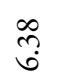 & $\hat{\sigma}$ & $\hat{\infty}$ & $\tilde{\hat{\sigma}}$ & $\begin{array}{l}\infty \\
\infty \\
i \\
i n\end{array}$ & कु. & $\begin{array}{l}\text { तु } \\
\text { }\end{array}$ & $\stackrel{+}{\text { స్ }}$ & ஸి & $\underset{\text { f̦ }}{\text { f. }}$ & $\stackrel{t r}{n}$ & $\stackrel{\infty}{\dot{n}}$ & $\stackrel{\widehat{+}}{+}$ & $\stackrel{\stackrel{\leftrightarrow}{n}}{\stackrel{\leftrightarrow}{n}}$ \\
\hline एक $\widehat{a}$ & $\hat{\widehat{\sigma}}$ & $\stackrel{\infty}{\infty}$ & के & $\stackrel{7}{6}$ & $\hat{\sigma}$ & $\hat{\infty}$ & $\stackrel{\infty}{\stackrel{\sim}{*}}$ & $\underset{\sim}{\stackrel{F}{n}}$ & ๑ & & $\begin{array}{c}\tilde{D} \\
\stackrel{\infty}{\infty}\end{array}$ & Oे. & $\underset{\text { f̧ }}{0}$ & ث্ & $\stackrel{\circ}{\stackrel{0}{0}}$ & $\underset{\sigma}{*}$ & $\stackrel{\circ}{\stackrel{n}{n}}$ \\
\hline $\bar{\oplus} \widehat{\varrho}$ & $\begin{array}{l}\stackrel{゚}{\stackrel{\infty}{\infty}} \\
\infty\end{array}$ & $\begin{array}{l}\text { ते } \\
\text { ஸे }\end{array}$ & $\underset{\infty}{\mathbb{\infty}}$ & హ) & $\underset{\infty}{\vec{\infty}}$ & $\stackrel{\infty}{m}$ & $\underset{\infty}{\stackrel{n}{\infty}}$ & \begin{tabular}{c}
0 \\
\multirow{\infty}{*}{} \\
$\infty$
\end{tabular} & $\stackrel{2}{\stackrel{0}{0}}$ & $\underset{\infty}{\stackrel{\infty}{\infty}}$ & $\underset{\substack{0 \\
\infty \\
\infty}}{ }$ & $\stackrel{ \pm}{\stackrel{ \pm}{0}}$ & $\tilde{n}$ & $\underset{\infty}{\stackrel{f}{0}}$ & $\stackrel{ }{\circ}$ & 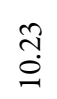 & $\underset{\infty}{\stackrel{+}{\infty}}$ \\
\hline$\therefore \widehat{a}$ & $\stackrel{a}{a}$ & $\tilde{n}$ & $\exists$ & $\frac{0}{\infty}$ & $\hat{\alpha}$ & $\underset{\sigma}{\stackrel{*}{*}}$ & $\stackrel{\Re}{n}$ & $\begin{array}{l}\text { Oे } \\
\stackrel{0}{\circ}\end{array}$ & ָ̦ & $\hat{n}$ & $\stackrel{\circ}{\circ}$ & $\stackrel{\infty}{\Lambda}$ & $\vec{\infty}$ & $\stackrel{\infty}{\sim}$ & హ) & ஓे & $\stackrel{\sim}{\sigma}$ \\
\hline 安 $\widehat{e}$ & 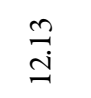 & $\stackrel{\mathbb{N}}{\stackrel{\text { I }}{=}}$ & 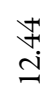 & $\stackrel{\Xi}{=}$ & $\stackrel{+t}{\Xi}$ & 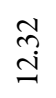 & $\stackrel{\tilde{m}}{\ddot{n}}$ & $\stackrel{n}{\tilde{z}}$ & 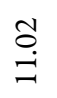 & & $\overrightarrow{\widehat{\varrho}}$ & 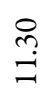 & $\vec{ָ}$ & $\begin{array}{l}\stackrel{0}{\simeq} \\
\stackrel{]}{]}\end{array}$ & $\stackrel{\widetilde{g}}{=}$ & $\stackrel{尺}{\stackrel{ }{=}}$ & $\begin{array}{l}\infty \\
\vdots \\
\stackrel{]}{1}\end{array}$ \\
\hline $\begin{array}{l}\vec{E} \\
\hat{E} \\
0\end{array}$ & 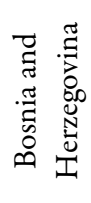 & 苂 & 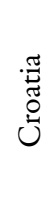 & 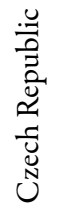 & 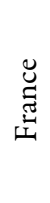 & 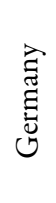 & 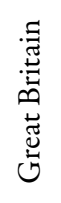 & 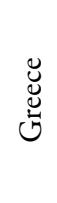 & 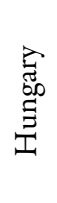 & 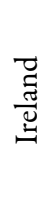 & 氙 & $\begin{array}{l}\overrightarrow{\vec{J}} \\
\frac{\vec{J}}{0} \\
\stackrel{0}{1}\end{array}$ & 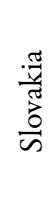 & 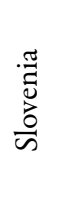 & 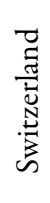 & 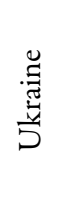 & 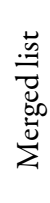 \\
\hline
\end{tabular}

Legends: Am - Amaranthaceae, Ap - Apiaceae, As - Asteraceae, Bo - Boraginaceae, $\mathrm{Br}$ - Brassicaceae, Ca - Caryophyllaceae,

$\mathrm{Fa}$ - Fabaceae, La - Lamiaceae, $\mathrm{Pa}$ - Papaveraceae, Pl - Plantaginaceae, Po - Poaceae, Ra - Ranunculaceae, Ro - Rosaceae. 
It is followed by the Brassicaceae and Poaceae families. The proportion of grasses is extremely high in Croatia, while in the Swiss and German lists those values are significantly lower compared to those of the merged list. In addition to the Asteraceae in the British Isles, the number of archaeophytes belonging to the Caprifoliaceae, Caryophyllaceae, Geraniaceae, Lamiaceae and Papaveraceae families is outstanding. At the same time, the Great Britain and Ireland have the fewest species in the Fabaceae family. In western European countries (British Isles and France), the proportion of Amaranthaceae species is low, and the lowest number of Rosaceae family can be observed in France. In contrast, Slovakia and the Czech Republic are characterized by high proportion of Rosaceae species compared to other examined areas. The percentage of Fabaceae species is the highest in the Southern European states (Italy, Greece and Crete). Plantaginaceae species predominantly occur in central and western European states (Switzerland, Ireland, Germany and Great Britain).

The three minor families (they are present in the list of only one, two, or three countries) include the Araliaceae, Cupressaceae and Vitaceae. At the same time, most of the 'one-species' families in the merged list are listed in 5-8 countries (Cyperaceae, Juglandaceae, Lauraceae, Linaceae, Moraceae, Myrtaceae, Paeoniaceae, Pinaceae, Platanaceae and Sapindaceae). Convolvulaceae, Lythraceae, Montiaceae and Verbenaceae, all of which contain a single taxon, have extensive distribution, because the species of these families can be found in all 15 examined areas.

Distribution of plant life-forms in national lists

Similarly, to the merged list, the annual species also represent the majority of archaeophytes in each of the 15 European countries. Their proportions exceed $50 \%$ in all countries. The ratio of therophytes is extremely high in the Polish list (57.2\%). The ratios of annual-biennial (Th-TH) and biennial (TH) species are remarkable in Great Britain (14.5\%; 5\%) and Ireland (14.6\%; 5\%).

The proportion of perennials is also significant in the merged list (13.6\%). The highest percentage $(14.8 \%)$ of hemicryptophytes occurred in the Slovak list. This life from is present in Switzerland and Germany in more than $14 \%$ of the archaeophytes. Geophytes have a significant number of taxa in the Hungarian, Swiss, French and Italian lists, considering the proportions (over 4\%). The proportion of large trees (MM) is considerable in the Cretan list (1.5\%), but large tree species are not found in Ukraine, Switzerland and Germany. The proportion of woody archaeophytes is also outstanding in the Balkan Peninsula and Italy. The majority of these plants have Mediterranean or Eurasian origin, so the consequences of the ancient trading networks and Turkish mediators might be observed in such distribution patterns.

Comparing the proportions of herbaceous and woody species in all national lists, herbaceous plants represent over $90 \%$ of species, a value similar to the merged list. The lowest number of herbaceous species can be found in Crete (90.7\%). Such a value is very high in Ukraine, Switzerland, Hungary, Ireland, Poland, Germany and Great Britain (over 94\%). According to Lososová et al. (2006) the proportion of perennials and woody plants is more prominent among neophytes.

\section{Distribution of national lists by geoelements categories}

Of all the national lists, Eurasian taxa have the highest rates (28-35\% of the lists). Cosmopolitan archaeophytes are present in 10-14\% of each area, with the largest amount occurring in the British Isles. Also, worth mentioning is the number of archaeophytes of southern origin (southern Eurasia, Mediterranean, subMediterranean, eastern Mediterranean). These four categories together constitute $24-40 \%$ of the list of some areas. The lowest number of southern geoelements can be observed on the Irish, British and German lists. The major differences are mainly due to different proportion of the Mediterranean area type plants. The least Mediterranean archaeophytes are in the Polish and German list (3.2-3.5\%). The number of Atlantic species in addition to Great Britain, Ireland and France in this flora region - can be considered high even in the German and Swiss national lists. The proportion of Central European archaeophytes reaches the highest percentage in Slovakia, while the Hungarian and Polish lists contain the highest number of Pontic geoelements. The 
488

proportion of circumpolar taxa in the sub Mediterranean-Mediterranean states (Croatia, Italy, BosniaHerzegovina, Greece) nearly half that in Ireland and United Kingdom (Table 2).

Table 2. Percentage of geoelements with high taxon numbers compared to the total number of archaeophytes, in the 15 national archaeophyte lists and the merged European archaeophyte list

\begin{tabular}{|c|c|c|c|c|c|c|c|c|c|c|c|}
\hline Country & Eua & Smed & Cosm & S-eua & Med & Eur & Atl & C-eu & Circ & Pont & $\begin{array}{c}\text { E-med- } \\
\text { smed }\end{array}$ \\
\hline $\begin{array}{c}\text { Bosnia and } \\
\text { Herzegovina }\end{array}$ & 28.70 & 11.66 & 10.54 & 10.76 & 15.47 & 9.19 & 3.59 & 2.47 & 2.24 & 2.69 & 2.69 \\
\hline Crete & 28.42 & 11.06 & 10.20 & 10.63 & 17.14 & 9.33 & 3.47 & 2.39 & 2.17 & 2.60 & 2.60 \\
\hline Croatia & 28.82 & 11.75 & 10.20 & 10.42 & 15.96 & 8.87 & 3.77 & 2.66 & 2.22 & 2.66 & 2.66 \\
\hline $\begin{array}{c}\text { Czech } \\
\text { Republic }\end{array}$ & 33.08 & 12.72 & 10.69 & 9.67 & 8.40 & 9.92 & 3.82 & 3.56 & 2.80 & 2.80 & 2.54 \\
\hline France & 29.10 & 11.94 & 11.19 & 10.45 & 14.18 & 9.95 & 5.22 & 2.49 & 2.49 & 2.24 & 0.75 \\
\hline Germany & 35.67 & 13.45 & 11.11 & 10.82 & 3.51 & 10.23 & 5.26 & 2.92 & 2.92 & 2.92 & 1.17 \\
\hline Great Britain & 34.85 & 9.13 & 14.11 & 7.47 & 7.47 & 10.79 & 7.88 & 3.32 & 4.15 & 0.41 & 0.41 \\
\hline Greece & 28.04 & 11.30 & 10.22 & 10.65 & 16.96 & 9.35 & 3.70 & 2.39 & 2.17 & 2.61 & 2.61 \\
\hline Hungary & 34.07 & 13.74 & 11.54 & 11.26 & 4.12 & 8.24 & 4.12 & 3.30 & 3.02 & 3.30 & 3.30 \\
\hline Ireland & 34.58 & 9.17 & 14.17 & 7.50 & 7.50 & 10.83 & 7.92 & 3.33 & 4.17 & 0.42 & 0.42 \\
\hline Italy & 28.44 & 11.11 & 10.22 & 9.78 & 17.11 & 9.78 & 4.44 & 2.22 & 2.22 & 2.44 & 2.22 \\
\hline Poland & 34.97 & 14.16 & 11.56 & 10.69 & 3.18 & 8.96 & 4.34 & 3.18 & 3.18 & 3.18 & 2.60 \\
\hline Slovakia & 34.20 & 12.69 & 10.36 & 10.36 & 6.48 & 9.59 & 3.89 & 4.15 & 2.85 & 2.85 & 2.59 \\
\hline Slovenia & 28.54 & 11.87 & 10.50 & 10.73 & 14.16 & 9.13 & 4.57 & 2.51 & 2.51 & 2.74 & 2.74 \\
\hline Switzerland & 34.20 & 13.91 & 11.59 & 10.72 & 5.22 & 9.57 & 5.22 & 2.90 & 2.90 & 2.61 & 1.16 \\
\hline Ukraine & 34.69 & 12.83 & 12.54 & 10.50 & 5.25 & 9.04 & 4.96 & 2.62 & 2.92 & 2.33 & 2.33 \\
\hline Merged list & 31.90 & 12.03 & 11.30 & 10.15 & 10.13 & 9.55 & 4.76 & 2.90 & 2.81 & 2.43 & 2.05 \\
\hline Legends
\end{tabular}

Legends: Eua - Eurasian, Smed - sub-Mediterranean, Cosm - cosmopolitan, S-eua - south Eurasian, Med Mediterranean, Eur - European, Atl - Atlantic, C-eu - Central-European, Circ - circumpolar, Pont- Pontic, E-medsmed - East-Mediterranean-sub Mediterranean

\section{Discussion}

There were significant differences in the sizes of the original lists, both in terms of the length of the lists (the Ukrainian list contains nine archaeophytes while that of the Czech Republic possess 312 species). This difference can be also stated in case of the comparison of neighbouring countries to some genera. These significant imbalances have disappeared in the case of revised or supplemented lists (198 of all the 560 species are included in the list of each area, with the shortest list containing 240 archaeophytes). As a tendency it can be observed that the length of the modified national lists is gradually decreasing northward from the Balkan Peninsula and from East to the West. It follows that we found the shortest archaeophyte list in the British Isles, which is explained by the historical-geographical processes (migration, Mongol invasion, Turkish conquest). By observing the gene centres the presence of anaecophyte archaeophytes is notable in the average of the studied areas (7.3\%). This value also expresses the uncertain phytogeographical status of archaeophytes. Because the original habitat of these hemerophytes species has already been destroyed and found only in anthropogenic environment (Pinke and Pál, 2005). Among these homeless species, for example Agrostemma githago, Sinapis arvensis and Tripleurospermum inodorum can be found in all lists. All three species can be used to indicate archaeophyte associations: corncockle can be considered a pH neutral plant (Andreasen and Skovgaard, 2009; Fried et al., 2010), charlock can be found in both northern and southern countries (Glemnitz et al., 2004), and scentless mayweed is also used as a signalling species because it is easy to identify and serves as an indicator of agro-biodiversity through the number of trophic connections (Hyvönen and Huusela-Veistola, 2008). When examining geoelements, it is evident that the proportion of Mediterranean and sub-Mediterranean taxa 
increases significantly in southern European areas. The same effect can be observed in the Atlantic countries: the presence of archaeophytes, which can be considered as Atlantic, is significantly higher in these countries than the others. However, the same effect cannot be observed in the lists of Central European or Pontic countries: we do not find a significant proportion of Central European or Pontic geoelements by examination. The explanation is that the proportion of Mediterranean (10.13\%) and sub-Mediterranean (12.03\%) geoelements is much higher among archaeophytes compared to Central European (2.90\%) or Pontic $(2.43 \%)$ geoelements.

\section{Conclusions}

In our study we compared archaeophytes of 15 European countries. By using distribution data, we have proposed to reduce anomalies between the lists published by each archaeophyte research, which may be particularly useful for the archaeophyte lists of neighbouring countries. We hope that our results will also help to judge disputed taxa. For future European lists, we recommend that, in addition to the definition of Preston et al. (2004), the authors should also take into account the available lists of neighbouring countries, geoelements and current distribution area of each taxon. Applying this approach will make it possible to establish a Europewide database which not only useful for the botanist.

\section{Acknowledgements}

This work was supported by EFOP-3.6.1-16-2016-00006 "The development and enhancement of the research potential at John von Neumann University" project. The Project is supported by the Hungarian Government and co-financed by the European Social Fund.

\section{Conflict of Interests}

The authors declare that there are no conflicts of interest related to this article.

\section{References}

Anastasiu P, Negrean G (2005). Alien plants in Romania (I). Analele Stiinţifice ale Universităţii “Al. I. Cuza” Iaşi 51:87-96.

Andreasen C, Skovgaard M (2009). Crop and soil factors of importance for the distribution of plant species on arable fields in Denmark. Agriculture Ecosystems and Environment 133:61-67. https://doi.org/10.1016/j.agee.2009.05.003

Arianoutsou M, Bazos I, Delipetrou P, Kokkoris Y (2010). The alien flora of Greece: taxonomy, life traits and habitat preferences. Biological Invasions 12:3525-3549. https://doiorg/10.1007/s10530-010-9749-0

Balogh L (2003). Az adventiv-terminológia s. l. négynyelvű segédszótára, egyben javaslat egyes szakszavak magyar megfelelőinek használatára [A quadrilingual auxiliary-dictionary of adventive-terminology s. l., and proposals for the use of certain terms in Hungarian]. Botanikai Közlemények 90:65-93.

Brun C (2009). Biodiversity changes in highly anthropogenic environments (cultivated and ruderal) since the Neolithic in eastern France. Holocene 19:861-871. http://dx.doi.org/10.1177/0959683609336559

Celesti-Grapow L, Alessandrini A, Arrigoni PV, Banfi E, Bernardo L, Bovio M, ... Blasi C (2009). Inventory of the non-native flora of Italy. Plant Biosystems 143:386-430. https://doi.org/10.1080/11263500902722824

Celesti-Grapow L, Alessandrini A, Arrigoni PV, Assini S, Banfi E, Barni E, ... Blasi C (2010). Non-native flora of Italy: Species distribution and threats. Plant Biosystems 144:12-28. https://doiorg/10.1080/1 1263500903431870 
Cin D'Agata C, Skoula M, Brundu G (2009). A preliminary inventory of the alien flora of Crete (Greece). Bocconea 23:301315.

Comin S, Poldini L (2009). Archaeophytes: Decline and dispersal - a behavioural analysis of a fascinating group of species. Plant Biosystems 143:46-55. https://doi.org/10.1080/11263500903192159

Erhardt W, Götz E, Bödeker N, Seybold S (2008). Der Große Zander Enzyklopädie der Pflanzennamen. Band 2: Arten und Sorten [The great Zander encyclopaedia of plant names. Book 2: Species and varieties]. Eugen Ulmer KG, Stuttgart.

Erhardt W, Götz E, Bödeker N, Seybold S (2002). Zander. Handwörterbuch der Pflanzennamen [Dictionary of plant names]. 17. Auflage. Eugen Ulmer GmbH, Stuttgart.

Euro+Med PlantBase (2006). The information resource for Euro-Mediterranean plant diversity. Retrieved 2018 February 20 from http://ww2.bgbm.org/EuroPlusMed/.

Fried G, Petit S, Reboud X (2010). A specialist-generalist classification of the arable flora and its response to changes in agricultural practices. BMC Ecology 10:1-11. https://doi.org/10.1186/1472-6785-10-20

GBIF.org (2019). Global Biodiversity Information Facility. Retrieved 2019 November 19 from https://www.gbif.org/

Glemnitz M, Hoffmann J, Radics L, Czimber L (2004). Composition of weed floras in different agricultural management systems within European climatic gradient. In: 6th EWRS Workshop on Physical and Cultural Weed Control. Hedmark University College, Lillehammer, Norway pp 58-68.

Hajnalová E, Hunková E, Šteffek J (1993). Nálezy organických zvyškov získaných preplavovaním a analýzou odtlačkov [Finds of organic remnants obtained by rinsing and analyses of imprints]. In: Hanuliak M, Kuzma I, Šalkovský P (Eds). MužlaČenkov I Osídlenie z 9.-12. storočia [Mužla-Čenkov I. Settlement from 9th to 12th Century]. Materialia Archaeologica Slovaca, Nitra pp 101-133.

Hofmeister H, Garve E (2006). Lebensraum Acker [Habitats of field]. Parey Buch Verlag, Berlin.

Hyvönen T, Huusela-Veistola E (2008). Arable weeds as indicators of agricultural intensity - a case study of Finland. Biological Conservation 141:2857-2864. http://dx.doi.org/10.1016/j.biocon.2008.08.022

Jogan J, Bačič M, Krajšek SS (2012). Tujerodne in invazivne rastline v Sloveniji [Non-native and invasive plants in Slovenia]. In: Jogan J, Bačič M, Krajšek SS (Eds). Neobiota Slovenije, končno poročilo projekta [Neobiota of Slovenia, final project report]. Oddelek za biologijo [Department of Biology] Ljubljana pp 161-182.

Király G (Ed) (2009). Új magyar füvészkönyv. Magyarország hajtásos növényei. Határozókulcsok [New Hungarian Herbal. Vascular plants of Hungary. Taxonomic keys]. Aggteleki Nemzeti Park Igazgatóság [Aggtelek National Park], Jósvafó.

Kovács P, Szigeti B (Eds) (2007). Földrajzi világatlasz [Geographic World Atlas]. Cartographia kft., Budapest.

Lososová Z, Chytrỷ M, Kühn I, Hájek O, Horáková V, Pysek P, Lubomír Tichỷ (2006). Patterns of plants traits in annual vegetation of man-made habitats in central Europe. Perspectives in Plant Ecology, Evolution and Systematics 8:69-81. https://doi.org/10.1016/j.ppees.2006.07.001

Maslo S, Abadžić S (2015). Vascular flora of the town of Bragaj (south Bosnia and Herzegovina). Natura Croatica 24(1):59-92. https://doi.org/10.20302/NC.2015.24.4

Maslo S (2014a). Alien flora of Hutovo Blato Natural Park (South Bosnia and Herzegovina). Herbologia 14(1):1-13. http://dx.doi.org/10.5644/Herb.14.1.01

Maslo S (2014b). The urban flora of the city of Mostar (Bosnia and Herzegovina). Natura Croatica 23:101-145.

Medvecká J, Kliment J, Májeková J, Halada L', Zaliberová M, Gojdičová E, ... Jarolímek I (2012). Inventory of alien flora of Slovakia. Preslia 84:257-309.

Meusel H, Jäger E, Weinert E (1965). Vergleichende Chorologie der zentraleuropäischen Flora [Comparative chorology of Central European flora]. Gustav Fischer Verlag, Jena.

Nikolić T (2018). Flora Croatica Database. Zagreb: Department of Botany, Faculty of Science, University of Zagreb. Retrieved 2018 February 25 from http://hirc.botanic.hr/fcd

Ööpik M, Kukk T, Kull K, Kull T (2008). The importance of human mediation in species establishment: analysis of the alien flora of Estonia. Boreal Environment Research 13:53-67.

Pinke Gy, Pál R (2005). Gyomnövények eredete, termőhelye és védelme [Origin, habitat and protection of weeds]. Alexandra Kiadó, Szeged.

Preston CD, Pearman DA, Hall AR (2004). Archaeophytes in Britain. Botanical Journal of the Linnean Society 145:257-294. http://dx.doi.org/10.1111/j.1095-8339.2004.00284.x 
Protopopova VV, Shevera MV (2014). Ergasiophytes of the Ukrainian flora. Biodiversity Research and Conservation 35(1):3146. https://doi.org/10.2478/biorc-2014-0018

Pykälä J (1998). Onko Suomessa sata vai kaksisataa muinaistulokaskasvia [100 or 200 archaeophytes in the flora of Finland]? Lutukka 14:5-57.

Pysek P, Danihelka J, Sádlo J, Chrtek J Jr, Chytrý M, Jarošík V ... TichýL (2012). Catalogue of alien plants of the Czech Republic (2nd edition): Checklist update, taxonomic diversity and invasion patterns. Preslia 84:155-255.

Richner NA (2014). Changes in arable weed communities over the last 100 years. PhD Dissertation, Universität Zürich, Zürich.

Sarajlic N, Jogan N (2017). Alien flora of the city of Sarajevo (Bosnia and Herzegovina). Biologica Nyssana 8:129-136. https://doi.org/10.5281/zenodo.1135952

Simon T (2000). A magyarországi edényes flóra határozója [Vascular flora of Hungary]. Harasztok - virágos növények [Ferns and flowering plants]. Nemzeti Tankönyvkiadó, Budapest.

Soó R (1964-1985). A magyar flóra és vegetáció rendszertani-növényföldrajzi kézikönyve - Synopsis systematico-geobotanica florae vegetationisque Hungariae I-VII [A taxonomic-phytogeographical handbook of Hungarian flora and vegetation]. Akadémiai Kiadó, Budapest.

Stevens PF (2017). Angiosperm Phylogeny Website. Version 14. Retrieved 2018 March 1 from http://www.mobot.org/MOBOT/research/APweb/

Suominen J, Hämet-Ahti L (1993). Archaeophytes in the flora of Finland. Norrlinia 4:1-90.

Terpó A, Zając M, Zając A (1999). Provisional list of Hungarian archeophytes. Thaiszia 9:41-47.

The International Plant Names Index (2012). Retrieved 2018 June 16 from https://www.ipni.org

The Plant List (2013). Version 1.1. Retrieved 2019 January 23 from http://www.theplantlist.org/

Tokarska-Guzik B, Węgrzynek B, Urbisz A, Urbisz A, Nowak T, Bzdęga K (2010). Alien vascular plants in the Silesian Upland of Poland: distribution, patterns, impacts and threats. Biodiversity Research and Conservation 19:33-54. https://doi.org/10.2478/v10119-010-0019-x

Verloove P (2006). Catalogue of neophytes in Belgium (1800-2005). Scripta Botanica Belgica 39:1-89.

Wąsowicz P (2018). The first attempt to list the archaeophytes of Iceland. Acta Societatis Botanicorum Poloniae 87(4):3608. https://doi.org/10.5586/asbp.3608

Williamson M, Stout JC, Dehren-Schmutz K, Milbau A, Hall AR (2008). A provisional list of Irish archaeophytes. Irish Naturalists' Journal 29:30-35.

Zając M, Zając A, Tokarska-Guzik B (2009). Extinct and endangered archaeophytes and the dinamics of their diversity in Poland. Biodiversity Research and Conservation 13(1):17-24. https://doi.org/10.2478/v10119-009-0004-4
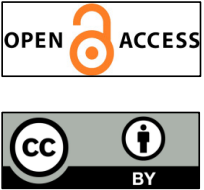

The journal offers free, immediate, and unrestricted access to peer-reviewed research and scholarly work. Users are allowed to read, download, copy, distribute, print, search, or link to the full texts of the articles, or use them for any other lawful purpose, without asking prior permission from the publisher or the author.

License - Articles published in Notulae Botanicae Horti Agrobotanici Cluj-Napoca are Open-Access, distributed under the terms and conditions of the Creative Commons Attribution (CC BY 4.0) License. (C) Articles by the authors; UASVM, Cluj-Napoca, Romania. The journal allows the author(s) to hold the copyright/to retain publishing rights without restriction. 